Ovozoa

Vol. 8, No. 2, Oktober 2019

ISSN: 2302-6464

\title{
PENGARUH PENAMBAHAN EKSTRAK TEH HIJAU (Camellia sinensis) DALAM BAHAN PENGENCER SUSU SKIM KUNING TELUR TERHADAP KUALITAS SPERMATOZOA DOMBA SAPUDI YANG DISIMPAN PADA SUHU DINGIN
}

\section{THE EFFECT OF THE ADDITION OF GREEN TEA EXTRACT (Camellia sinensis) IN SKIM MILK AND EGG YOLK DILUENT FOR QUALITY SAPUDI SHEEP SPERMATOZOA PRESERVED ON COLD TEMPERATURE}

\author{
Wahyu Retno Swari' ${ }^{1)}$, Emy Koestanti Sabdoningrum ${ }^{2)}$, Wurlina ${ }^{3)}$, \\ *Suherni Susilowati ${ }^{4)}$, Rochmah Kurnijasanti ${ }^{5)}$, Erma Safitri ${ }^{6}$ ) \\ ${ }^{1)}$ Student, ${ }^{2}$ Departement of Livestock, ${ }^{3,4,6}$ Departement of Veterinary Reproduction, \\ ${ }^{5)}$ Departement of Veterinary Basic Medical Science \\ Faculty of Veterinary Medicine, Universitas Airlangga \\ *Corresponding author: email: suhernifkhunair@gmail.com; wahyuretno586@gmail.com
}

\begin{abstract}
The purpose of this study was to determinated the effect and the best concentration of greentea extract in skim milk and egg yolk diluent for quality sapudi sheep spermatozoa were measured in motility, viability and intact plasma membrane that was stored on cold temperature. The semen was devided into four groups; skim milk and egg yolk diluent, $0,5 \%$ green tea extract in skim milk and egg yolk diluent, $0,1 \%$ green tea extract in skim milk and egg yolk diluent, and $0,15 \%$ green tea extract in skim milk and egg yolk diluent. Spermatozoa quality was observed day 1, day 2, day 3, day 4 and day 5 after being diluted. The data obtained was analyzed with the Analysis of Variant (ANOVA), followed by multiple range test duncan. The results showed that the highest percentage of motility, viability and intact plasma membrane derived from green tea extract $0,15 \%$ on skim milk and egg yolk diluent for 1 day storage is $86.66^{\mathrm{b}} \pm 2.58,92.00^{\mathrm{b}} \pm 1.78$, and $74.16^{\mathrm{b}} \pm 3.25$. The lowest percentage of motility, viability and intact plasma membranes was obtained from the skim milk and egg yolk diluent for 5 days storage is $43.33^{\mathrm{a}} \pm 6.05,56.50^{\mathrm{a}} \pm 3.08$ and $28.33^{\mathrm{a}} \pm 2.80$. The conclusion of this study is the addition of $0.15 \%$ green tea extract in a skim milk and egg yolk diluent can maintain the quality of sperm for up to 5 days of storage at cold temperatures.
\end{abstract}

Keywords: Skim milk and egg yolk, green tea extract, sperm quality, Sapudi sheep

\section{Pendahuluan}

Inseminasi Buatan (IB) merupakan suatu bioteknologi dalam bidang reproduksi ternak yang diciptakan manusia guna meningkatkan produktivitas dan repoduksi ternak, untuk me-ngatasi tuntutan masyarakat yang semakin meningkat jumlahnya setiap tahun. Pelaksanaan IB di lapangan dimulai dengan pemilihan pejantan unggul. Pada pejantan dilakukan penampungan semen, penilaian kelayakan kualitas semen, pengolahan dan pengawetan semen dalam bentuk beku, serta teknik inseminasi yaitu dengan cara penempatan (inseminasi/deposisi) ke dalam saluran reproduksi betian (Kartasudjana, 2011).
Keberhasilan pelaksanaan IB sangat diten-tukan oleh beberapa faktor yaitu kesuburan betina, inseminator, ketepatan waktu inseminasi, dan kualitas semen yang digunakan. Kualitas semen untuk IB harus memenuhi persyaratan seperti volume, warna, $\mathrm{pH}$, konsistensi, motilitas, konsentrasi, dan morfologi sperma agar kualitas semen dapat dipertahankan. Segera setelah penampungan, semen perlu diencerkan dengan bahan pengencer untuk diawetkan. Semen perlu diencerkan terlebih dahulu dalam mempertahankan kualitas semen selama penyimpanan (Mumu, 2009).

Penyimpanan spermatozoa dapat dilakukan dengan proses kriopreservasi. 
Proses kriopreservasi membutuhkan bahan pengencer dan krioprotektan untuk mempertahankan fertilitas spermatozoa (Hardijanto dkk., 2010). Komposisi bahan pengencer yang digunakan untuk kriopreservasi semen diharapkan dapat mampu melindungi spermatozoa dari kejut dingin, mempertahankan motilitas dan kemampuan fertilitas spermatozoa, serta menjaga kestabilan membran plasma dan ketersediaan substrat energi untuk spermatozoa. Hal ini penting untuk mengurangi efek negatif perubahan $\mathrm{pH}$ dan osmolaritas, mencegah pertumbuhan bakteri, dan melindungi sel-sel spermatozoa dari kerusakan yang disebabkan oleh proses pendinginan, pembekuan, dan pencairan kembali (Futino et al., 2010).

Kuning telur merupakan krioprotektan ekstraseluler mengandung lipoprotein dan lesitin yang melindungi integritas sel spermatozoa selama penyimpanan $5^{\circ} \mathrm{C}$ dengan mempertahankan integritas selubung lipoprotein, selain itu glukosa dalam kuning telur menguntungkan spermatozoa karena adanya daya viskositas (Said dkk., 2005). Susu skim mengandung zat nutrisi yang dapat dimanfaatkan oleh spermatozoa sebagai sumber energi. Susu skim juga mengandung zat lipoprotein dan lesitin sehingga bisa digunakan dalam pengencer semen untuk melindungi spermatozoa dari pengaruh kejut dingin (cold shock) dan air susu juga mengandung enzim yang hancur pada pemanasan di atas $80^{\circ} \mathrm{C}$ yang dapat melepaskan gugus sulfhyhidril (-SH) yang berfungsi sebagai zat reduktif yang mengatur metabolisme oksidatif sperma (Widjaya, 2011).

Radikal bebas yang ada di lingkungan me-rupakan salah satu penyebab spermatozoa men-jadi abnormal. Salah satu jenis radikal bebas adalah Reactive Oxygen Species (ROS). ROS adalah radikal bebas yang punya peran penting pada beberapa proses fisiologis spermatozoa seperti kapasitasi, hiperaktivasi, reaksi akrosom, dan fusi dengan oosit (Agarwal dkk., 2005). Spermatozoa membutuhkan ROS pada level rendah untuk menginduksi proses kapasitasi dan pada reaksi akrosom, serta berikatan dengan zona pelusida sehingga dapat berlangsung proses fertilisasi
(Sikka, 2004; Sanoeka dan Kurpisz, 2004). Saleh dan Agarwal (2002) menyatakan ROS pada level tinggi berpotensi toksik terha-dap kualitas dan fungsi spermatozoa.

Penelitian terdahulu menyebutkan bahwa penambahan zat antioksidan pada pengencer me-miliki manfaat yang cukup baik diantaranya mencegah aktivitas radikal bebas terhadap kerusakan membran sel spermatozoa yang berpengaruh terhadap viabilitas dan fertilitas spermatozoa, berperan sebagai sumber energi untuk mempertahankan motilitas spermatozoa, disamping itu juga untuk memperbaiki komposisi dari pengencer tersebut (Aslam dkk., 2014; Lubis dkk., 2013).

Teh hijau (Camellia sinensis) memiliki kandungan antioksidan alami yaitu flavonoid. Katekin adalah golongan senyawa flavonoid yang paling penting dalam daun teh. Sulistyo dkk. (2003) meyebutkan bahwa teh hijau merupakan sumber antioksidan potensial karena di dalamnya ada unsur antioksidan EGCG (epigallocatechin-gallate) dan senyawa katekin lainnya.

\section{Materi Dan Metode \\ Sampel dan Besaran Sampel}

Sampel yand digunakan dari penelitian ini adalah 1 ekor domba Sapudi yang berada di Kandang Peternakan Fakultas Kedokteran Uni-versitas Airlangga. Semen diambil dalam 1 kali ejakulasi dan pengambilan sampel dilakukan 2 kali dalam seminggu.

\section{Cara Pembuatan Ekstrak Teh Hijau (Camellia sinensis)}

Ekstrak daun teh hijau diperoleh dari daun teh kering yang didapatkan dari Bandung, Jawa Barat. Lalu dilakukan proses maserasi menggunakan pelarut ethanol $96 \%$. Melakukan Freeze Drying agar diperoleh ekstrak padat, dan dihaluskan dengan mortar agar terbentuk sediaan serbuk.

\section{Pembuatan Susu Skim Kuning Telur}

Pembuatan bahan pengencer susu skim kuning telur yaitu 10 gram susu bubuk skim dimasukkan ke dalam beaker glass kemudian ditambahkan akuades 100ml, diaduk hingga homogen dan dipanaskan diatas penangas 
sam-pai suhu $92-95^{\circ} \mathrm{C}$ selama 10 menit. Air susu ter-sebut didinginkan sampai mencapai suhu ruang $\left(20-32^{\circ} \mathrm{C}\right)$. Kuning telur ditambahakan ke dalam $100 \mathrm{ml}$ susu skim sebanyak $5 \mathrm{ml}(5 \%)$. Selanjutnya diaduk sampai homogen dan ditam-bahkan antibiotik Penicilin $1000 \mathrm{IU} / \mathrm{ml}$ pengen-cer dan Streptomycin $1 \mathrm{mg} / \mathrm{ml}$.

\section{Pembagian Kelompok Perlakuan}

(P0) : 1:10 semen + susu skim kuning telur

(P1) : 1:10 semen $+0,05 \%$ ekstrak teh hijau/100 $\mathrm{ml}$ pengencer susu skim kuning telur

(P2) : 1:10 semen $+0,1 \%$ ekstrak teh hijau/100 ml pengencer susu skim kuning telur

(P3) : 1:10 semen $+0,15 \%$ ekstrak teh hijau/100 ml pengencer susu skim kuning telur

Derajat keasaman $(\mathrm{pH})$ dari setiap perlakuan diukur sebelum dimasukkan ke dalam tabung reaksi dan ditutup rapat. Selanjutnya, tabung dimasukkan ke dalam beaker glass yang berisi air bersih dan dipreservasi di dalam lemari es (refrigerator) yang bersuhu $5^{\circ} \mathrm{C}$. Masing-masing perlakuan dievaluasi kualitasnya setiap hari sela-ma 5 hari hingga persentase motilitas spermato-zoa progresif $\leq 40 \%$. Pemeriksaan dilakukan untuk mengetahui persentase motilitas, viabilitas dan integritas membran plasma spermatozoa.

\section{Tempat dan Waktu Penelitian}

Penelitian ini dilaksanakan di Laboratorium Inseminasi Buatan Departemen Reproduksi Veteriner Fakultas Kedokteran Hewan Unviversitas Airlangga. Pembuatan ekstrak teh hijau dilakukan di Departemen Kedokteran Dasar Veteriner Fakultas Kedokteran Hewan Universitas Airlangga, Surabaya. Penelitian ini dilaksanakan bulai Mei-Juni 2018.

\section{Bahan dan Alat Penelitian}

Bahan-bahan penelitian meliputi : semen domba Sapudi, susu skim, kuning telur, daun teh hijau kering, etanol 96\%, penisilin, streptomycin, fruktosa, larutan pewarna eosin- negro-sin, vaselin, air hangat, $\mathrm{NaCl}$ fisiologis, larutan HOS, akuades dan alkohol $70 \%$.

Peralatan yang digunakan dalam penelitian ini adalah : 1 set vagina buatan, tabung berskala, ta-bung reaksi, rak tabung, timbangan mikro, erlen-meyer, kertas saring, kertas label, spuilt $1 \mathrm{ml}$, batang pengaduk, pembakar bunsen, termos air, mikroskop cahaya, gelas objek, gelas penutup, thermometer, gelas ukur, kertas $\mathrm{pH}$, pipet tetes, pipet hisap, aluminium foil, tissu, lemari pen-dingin, mesin giling, rotary evaporator, freeze dryer, dan mortar.

\section{Pengolahan Data}

Data yang diperoleh berupa rata-rata dan simpangan baku. Data hasil perbedaan motilitas, viabilitas, dan membran plasma utuh pada kelompok perlakuan dianalisis menggunakan Analysis of Variant (ANOVA). Jika terdapat perbedaan, maka dilanjutkan dengan uji jarak berganda Duncan (Kusriningrum, 2010). Seluruh data disajikan menggunakan fasilitas SPSS 22 for Windows.

\section{Hasil Dan Pembahasan Penelitian Motilitas Setelah Pengenceran}

Hasil pada penelitian ini menunjukkan rata-rata persentase motilitas spermatozoa domba Sapudi dari nilai tertinggi hingga nilai terendah yang disimpan pada suhu dingin pada hari ke-5 adalah P3 sebesar 56,66\%, P2 sebesar 53,33\%, P1 sebesar 50\%, dan P0 sebesar $43,3 \%$. Semakin tinggi penambahan ekstrak teh hijau, persentase motilitas spermatozoa domba Sapudi yang dipertahankan juga semakin tinggi. Pengaruh ini dapat disebabkan karena pada teh hijau terdapat senyawa antioksidan potensial khususnya senya-wa katekin yang dapat menurunkan ROS. Dengan adanya penambahan antioksidan berupa ekstrak teh hijau dalam pengencer susu skim kuning telur juga akan memperbaiki komposisi dari pengencer tersebut. Risal dan Herdis (2010) menyatakan bahwa beberapa penelitian terda-hulu menunjukkan bahwa penambahan antioksidan ke dalam pengencer semen dapat meningkatkan kualitas semen beku yang 
dihasilkan melalui pencegahan kerusakan pada akrosom.

\section{Viabilitas Setelah Pengenceran}

Hasil pada penelitian ini menunjukkan rata-rata persentase viabilitas spermatozoa domba Sapudi dari nilai tertinggi hingga nilai terendah yang disimpan pada suhu dingin pada hari ke-5 adalah P3 sebesar 68\%, P2 sebesar $66,16 \%$, P1 sebesar $64,83 \%$, dan P0 sebesar $56,50 \%$. Semakin tinggi penambahan ekstrak teh hijau, persentase viabilitas spermatozoa domba Sapudi yang dipertahankan juga semakin tinggi. Hal ini sesuai dengan pernyataan Aslam dkk. (2014) Penelitian terdahulu menyebutkan bahwa penambahan zat antioksidan pada pengencer memiliki manfaat yang cukup baik diantaranya mencegah aktivitas radikal bebas terhadap kerusakan membran sel spermatozoa yang berpengaruh terhadap viabilitas dan fertilitas spermatozoa. Potensi antioksidan dari polifenol teh hijau khususnya senyawa katekin, secara langsung berhu-bungan dengan kombinasi cincin aromatis dan kelompok hidroksil. Polifenol teh hijau mendorong aktivitas detoksifikasi komponen xeno-biotika dan juga dapat meningkatkan ion logam seperti besi yang mengakibatkan radikal bebas oksigen (Imanulkhan, 2006).

\section{Keutuhan Membran Plasma Setelah Pengen-ceran}

Hasil pada penelitian ini menunjukkan rata-rata persentase membran plasma utuh sperma-tozoa domba Sapudi dari nilai tertinggi hingga nilai terendah yang disimpan pada suhu dingin pada hari ke-5 adalah P3 sebesar 35\%, P2 sebesar 33,3\%, P1 sebesar $32 \%$, dan P0 sebesar 28,3\%. Semakin tinggi penambahan ekstrak teh hijau, persentase membran plasma utuh sperma-tozoa domba Sapudi yang dipertahankan juga semakin tinggi. Tingginya persentase membran plasma utuh spermatozoa pada penambahan eks-trak teh hijau dalam pengencer susu skim kuning telur karena adanya kandungan antioksidan berupa polifenol yaitu senyawa katekin. Senyawa antioksidan yang ada pada teh hijau dapat menurunkan produksi ROS, senyawa ROS mengakibatkan peroksidasi lipid yang dapat memicu hilangnya keutuhan membran plasma spermatozoa. Hal tersebut sesuai dengan pendapat Naghma dan Mukhtar. (2007) bahwa Teh hijau (Camellia sinensis) dapat mengurangi produksi ROS dengan melengkapi elektron yang tidak berpasangan sehingga mengurangi kerusakan protein, membran lipid, dan asam nukleat.

\section{Kesimpulan}

Penambahan ekstrak teh hijau $0,15 \%$ dalam pengencer susu skim kuning telur dapat mem-pertahankan persentase motilitas, viabilitas, dan membran plasma utuh paling baik pada spermatozoa domba Sapudi yang disimpan pada suhu dingin dibandingkan dengan semua perla-kuan.

\section{Daftar Pustaka}

Agarwal, A., S. A. Prabakaran dan T. M. Said. 2005. Prevention of Oxydative Stress Minireview: Injury to Sperm. Journal of Andrology. 6 (26): 54-69.

Aslam, H. A., Dasrul dan Rosmaidar. 2014. Pengaruh Penambahan Vitamin $\mathrm{C}$ dalam Pengencer Andromed terhadap Persentase Motilitas dan Membran Plasma Utuh Spermatozoa Sapi Aceh Setelah Pembekuan. Jurnal Medika Veterina. 8 (1): 20-26.

Futino, D., M. Mendes., W. Matos., R. Mondadori and C. Lucci. 2010. Glycerol, Methyl-Formamide and Dimethyl-Formamide in Canine Semen Cryopre-servation. Reprod. Domest. Anim. 45: 214-220.

Hardijanto, T., Sarjito., T. Hernawati dan T. W. Suprayogi. 2010. Buku Ajar Fisiologi dan Teknologi Reproduksi (IB). Airlangga University Press. Surabaya.

Imanulkhan, 2006. Karakterisasi "Edibel Film" Beraktivitas dari Pati Ganyong (Canna edulis kerr) dan Ekstrak Teh Hijau (Camellia sinensis). Skripsi Mahasiswa Jurusan Teknologi Hasil Pertanian. Fakultas Teknologi Pertanian, Universitas Brawijaya. Malang. 
Kartasudjana, 2001. Teknik Inseminasi Buatan pada Ternak. Departemen Pendidikan Nasional.

Lubis, T. M., Dasrul., C. L. Thasmi dan T. Akbar. 2013. Efektivitas Penambahan Vitamin C dalam Pengencer Susu Skim Kuning Telur terhadap Kualitas Spermatozoa Kambing Boer Setelah Penyimpanan Dingin. Jurnal S. Pertanian. 3(1): 347-361.

Mumu, M. I. 2009. Viabilitas Semen Sapi Simmental yang Dibekukan Menggunakan Krioprotektan Gliserol. Journal Agroland. 16(2): 172-179.

Naghma, $K$ and H. Mukhtar. 2007. Tea Polyphenols for Health Promotions. Life Science. 81(7): 519-533.

Risal, M dan Herdis. 2010. Peranan Antioksidan dalam Meningkatkan Kualitas Semen Beku. Wartazoa. 20(3).

Said, S., M. Gunawan., E. M. Kaiin and B. Tappa. 2005. Daya Tahan Sperma Cair Sapi Simmental yang Disimpan dalam Straw dalam Temperatur $5^{\circ} \mathrm{C}$. Artikel Ilmiah. Cibinang. Pusat Penelitian Bioteknologi. LIPI.
Saleh, R. A dan A. Agarwal. 2002. Oxidative Stress and Male Infertility: from research bench to clinical practice. Journal Andrology. 23(6): 37-52.

Sanoeka, D and M. Kurpisz. 2004. Reactive Oxygen Species and Sperm Cells. Reprod. Biol. Endoc. 2(12): 112-117.

Sikka, S. C. 2004. Role of Oxydative Stress and Antioxidants in Andrology and Assisted Reproductive Technology. Journal Andrology. 25(1): 5-18.

Sulistyo, J., Nurdiana dan H. Elizar. 2003. Pengembangan Kerja Sama Riset. Teknologi, Produksi dan Pemasaran Produk Hilir Teh. Prosiding "Simposium Teh Nasional 2003". Pusat Penelitian Teh dan Kina Gambung. Bandung.

Widjaya, N. 2011. Pengaruh Pemberian Susu Skim dengan Pengencer Tris Kuning Telur terhadap Daya Tahan Hidup Spematozoa Sapi pada Suhu Penyimpanan $5^{\circ} \mathrm{C}$. Fakultas Pertanian Universitas Bandung Raya. 